Article

\title{
Differential MicroRNA Expression of miR-21 and miR-155 within Oral Cancer Extracellular Vesicles in Response to Melatonin
}

\author{
Matthew Hunsaker ${ }^{1}$, Greta Barba ${ }^{1}$, Karl Kingsley ${ }^{2, *}$ and Katherine M. Howard ${ }^{2}$ \\ 1 Department of Clinical Sciences, School of Dental Medicine, University of Nevada, Las Vegas, $1700 \mathrm{~W}$. \\ Charleston Blvd., Las Vegas, NV 89106, USA; matthew.hunsaker@sdm.unlv.edu (M.H.); \\ greta.barba@sdm.unlv.edu (G.B.) \\ 2 Department of Biomedical Sciences, University of Nevada, Las Vegas-School of Dental Medicine, \\ 1001 Shadow Lane, Las Vegas, NV 89106, USA; katherine.howard@unlv.edu \\ * Correspondence: Karl.Kingsley@unlv.edu; Tel.: +1-702-774-2623
}

Received: 17 December 2018; Accepted: 17 April 2019; Published: 1 May 2019

\begin{abstract}
Objective: Extracellular vesicles derived from oral cancer cells, which include Exosomes and Oncosomes, are membranous vesicles secreted into the surrounding extracellular environment. These extracellular vesicles can regulate and modulate oral squamous cell carcinoma (OSCC) progression through the horizontal transfer of bioactive molecules including proteins, lipids and microRNA (miRNA). The primary objective of this study was to examine the potential to isolate and evaluate extracellular vesicles (including exosomes) from various oral cancer cell lines and to explore potential differences in miRNA content. Methods: The OSCC cell lines SCC9, SCC25 and CAL27 were cultured in DMEM containing 10\% exosome-free fetal bovine serum. Cell-culture conditioned media was collected for exosome and extracellular vesicle isolation after $72 \mathrm{~h}$. Isolation was completed using the Total Exosome Isolation reagent (Invitrogen) and extracellular vesicle RNA was purified using the Total Exosome RNA isolation kit (Invitrogen). Extracellular vesicle miRNA content was evaluated using primers specific for miR-16, -21, -133a and -155. Results: Extracellular vesicles were successfully isolated from all three OSCC cell lines and total extracellular vesicle RNA was isolated. Molecular screening using primers specific for several miRNA revealed differential baseline expression among the different cell lines. The addition of melatonin significantly reduced the expression of miR-155 in all of the OSCC extracellular vesicles. However, miR-21 was significantly increased in each of the three OSCC isolates. No significant changes in miR-133a expression were observed under melatonin administration. Conclusions: Although many studies have documented changes in gene expression among various cancers under melatonin administration, few studies have evaluated these effects on microRNAs. These results may be among the first to evaluate the effects of melatonin on microRNA expression in oral cancers, which suggests the differential modulation of specific microRNAs, such as miR-21, miR-133a and miR-155, may be of significant importance when evaluating the mechanisms and pathways involved in melatonin-associated anti-tumor effects.
\end{abstract}

Keywords: microRNA; oral cancer; melatonin

\section{Introduction}

Many health benefits have been associated with melatonin expression and in more recent years, melatonin supplementation-including effects on sleep regulation and modulation in various states of health and disease [1-3]. Additional studies have demonstrated that melatonin may have beneficial effects on other conditions ranging from cardiovascular physiology, malarial disease, and neuropsychological conditions and delirium prevention [4-7]. These studies have prompted greater 
examinations of the potential for melatonin and other complementary and alternative therapies to integrate with cancer therapy and treatment $[8,9]$.

Due to the nature, structure and function of melatonin, much of this research has focused on hormone-dependent tumors, such as breast and pancreatic cancers [10-12]. However, the preventive and therapeutic actions of melatonin have also been observed in many other types of tumors, including oral and esophageal cancers [13-17]. Many of these effects have been associated with the potential for transcriptional modulation of genes important to oncogenesis and cancer progression, including apoptosis, proliferation and angiogenesis [18-20].

More recent studies have demonstrated that melatonin may also modulate the expression of non-coding microRNAs (or, miRNA), which modulate many aspects of tumor phenotypes in breast, liver and gastric cancers [21-23]. In fact, melatonin may modulate expression of specific microRNAs that function across multiple tumor types, such as miR-155, miR-133a and miR-21 [24-26].

Although previous studies from this group have evaluated changes to oral cancer gene expression under melatonin administration, as well as differential expression of oral cancer exosomes, extracellular vesicles, and microRNAs, no studies to date have analyzed the effects of melatonin on microRNA expression in oral cancers $[27,28]$. Based upon the paucity of evidence in this area, the primary goal of this project was to evaluate the effects of melatonin administration on the expression of specific microRNAs, such as miR-21, miR-133a and miR-155 among oral cancers.

\section{Methods}

\subsection{Tissue Culture}

Three human oral squamous cell carcinoma cell lines were obtained from American Tissue Type Culture Collection (Manassas, VA, USA): SCC9 (CRL-1629), SCC25 (CRL-1628) and CAL27 (CRL-2095). Cell cultures were maintained in Dulbecco's Modified Eagle's Medium (DMEM) from Hyclone (Logan, UT, USA) using the formulation with $4.0 \mathrm{mM} \mathrm{L}$-glutuamine, $4.5 \mathrm{~g} / \mathrm{L}$ glucose and $110 \mathrm{mg} / \mathrm{L}$ sodium pyruvate. DMEM was further supplemented with streptomycin $(100 \mu \mathrm{g} / \mathrm{mL})$ and penicillin $(100 \mathrm{U} / \mathrm{mL})$ and $10 \%$ fetal bovine serum (FBS) also obtained from Hyclone. Cell cultures were maintained in BD Falcon (Bedford, MA, USA) tissue culture treated flasks in humidified tissue culture incubators with $5 \% \mathrm{CO}_{2}$ at $37^{\circ} \mathrm{C}$.

\subsection{Reagents}

Melatonin ( $N$-acetyl-5-methoxy-tryptamine) used in this study was purchased from Thermo Fisher Scientific (Fair Lawn, NJ, USA). Each experiment was performed with and without the addition of melatonin to the cell culture medium at $10 \mu \mathrm{g} / \mathrm{mL}$ for $72 \mathrm{~h}$, as previously described [28]. This concentration was selected to approximate serum concentrations of melatonin found in serum and saliva following administration as an over-the-counter supplement [28-30]. Non-treated cells were used as the negative control and each experiment was repeated in triplicate $(n=3)$ for each cell line and both conditions (negative control, experimental).

\subsection{Intact Exosome Isolation}

Cell cultures were transferred into DMEM containing exosome-depleted FBS (with and without the addition of melatonin) for the $24 \mathrm{~h}$ before the isolation of exosomes. In order to remove any cells or cellular debris, the conditioned medium was removed from each tissue culture flask and centrifuged at $2000 \times g$ for $30 \mathrm{~min}$. The supernatant was then extracted and combined with Total Exosome Isolation reagent from Life Technology (Waltham, MA) and refrigerated overnight according to the manufacturer protocol. Extracellular vesicles were then isolated by centrifugation at $10,000 \times g$ at $4{ }^{\circ} \mathrm{C}$ for one hour. The exosome-containing pellets were resuspended in $200 \mu \mathrm{L}$ of Phosphate Buffered Saline (PBS) solution. 


\subsection{RNA Extraction from Exosomes}

An equal volume of $2 X$ Denaturing solution from Life Technology was added to the exosome resuspension and incubated on ice for five minutes. One volume of Phenol:Chloroform was added to the solution and centrifuged at $10 \times g$ at $4{ }^{\circ} \mathrm{C}$ for five minutes. The upper (aqueous) phase was removed and 1.25 volumes of ethanol $(\mathrm{EtOH})$ were then added. The sample was then transferred into a filter and centrifuged at $10 \times g$ for $15 \mathrm{~s}$. Each sample/filter was then washed using miRNA Wash Solution 1 and centrifuged at $10 \times g$ for $15 \mathrm{~s}$ before repeating this process with Wash Solution 2/3. To remove any residual fluid, each sample/filter was then centrifuged for 15 additional seconds. Each filter was then placed into a new collection tube and $100 \mu \mathrm{L}$ of heated RNase water was applied prior to centrifugation for $30 \mathrm{~s}$. The exosome RNA was contained in the collected flow through.

\subsection{TaqMan microRNA Assays}

Reverse transcription was accomplished using $15 \mathrm{~L}$ reactions that consisted of 10X Reverse Transcription Buffer, RNase inhibitor, $100 \mathrm{mM}$ deoxyribonucleotide triphosphate (dNTP) and MultiScribe Reverse Transcriptase containing $3 \mathrm{~L}$ of miR specific primer. Thermal cycler settings were $16{ }^{\circ} \mathrm{C}$ for $30 \mathrm{~min}, 42^{\circ} \mathrm{C}$ for $30 \mathrm{~min}, 85^{\circ} \mathrm{C}$ for five minutes, followed by cooling to $4{ }^{\circ} \mathrm{C}$.

Quantitative polymerase chain reaction (qPCR) was accomplished in $20 \mu \mathrm{L}$ reactions using the TaqMan Small RNA assay, TaqMan Universal PCR Master Mix II and corresponding product from the reverse transcription reaction. Thermal cycler settings were $50{ }^{\circ} \mathrm{C}$ for two minutes, $95^{\circ} \mathrm{C}$ for $10 \mathrm{~min}$, then 40 cycles of $95^{\circ} \mathrm{C}$ for $15 \mathrm{~s}$ and $60^{\circ} \mathrm{C}$ for $60 \mathrm{~s}$. Standard curves were made doing a five-fold serial dilution of cDNA for miR-16, the endogenous reference gene (positive control) for exosomal miRNA.

\subsection{Statistical Analysis}

Two-tailed t-tests were used to assess any statistical differences between the relative quantity of microRNAs (miR-21, miR-133a, miR-155) isolated from each cell line under control and experimental conditions. Histograms of qPCR expression are reported, including standard deviation (SD). Statistical significance was set at an alpha level, $\alpha=0.05$.

\section{Results}

Each of the three oral cancer cell lines generated visible exosome precipitation pellets from both the control and experimental assays, which were then processed to extract exosome RNA for quantitative PCR. The TaqMan MicroRNA assays for miR-21, miR-133a and miR-155 were performed and standard curves generated from cDNAs, thus allowing for relative quantitation of each of the target microRNAs.

The results for miR-21 demonstrated that all three oral cancer cell lines exhibited miR-21 expression in the extracellular vesicle isolates, although the relative expression of miR-21 varied considerably (Figure 1). For example, the relative quantity of miR-21 in extracellular vesicles isolated from CAL27 and SCC9 in the negative controls was similar, but significantly lower than was observed in SCC25 cells. The addition of melatonin induced significant increases in the relative quantity of miR-21 in extracellular vesicles from all three cell lines (CAL27, SCC9, SCC25)—regardless of the baseline expression observed $(p<0.05)$.

The results for miR-133a also demonstrated that each of the oral cancer cell lines harbored miR-133a within their respective extracellular vesicles, with differential expression also observed (Figure 2). For example, the relative quantity of miR-133a in extracellular vesicles isolated from CAL27 was significantly lower than that observed from either SCC9 or SCC25-although the greatest relative quantity was observed from SCC9. However, the addition of melatonin did not have any significant or observable effect on the relative quantity of miR-133a in extracellular vesicles from any of the oral cancer cell lines in this study (CAL27, $p=0.11$; SCC9, $p=0.634$; SCC25, $p=0.411$ ). 


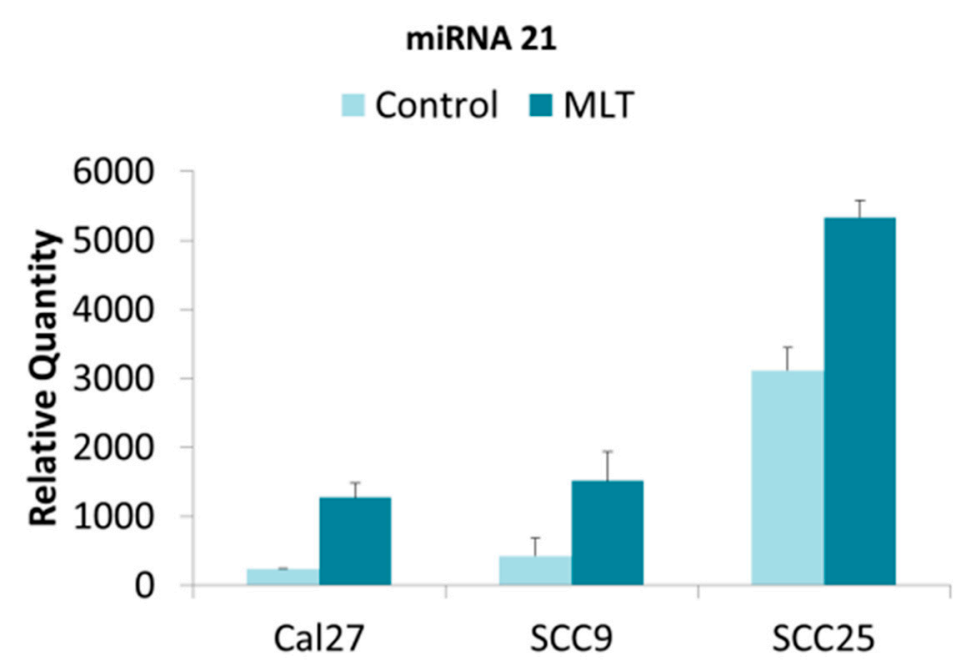

Figure 1. Relative miR-21 expression in oral cancers under melatonin (MLT) administration. Histogram of quantitative PCR from cDNAs derived from extracellular vesicles demonstrated differential baseline expression of miR-21 including standard deviation (SD), which was significantly increased in all cell lines under melatonin administration, $p<0.05$ (CAL27, $p<0.001$; SCC9, $p<0.001$; SCC25, $p<0.001$ ).

\section{miRNA 133a}

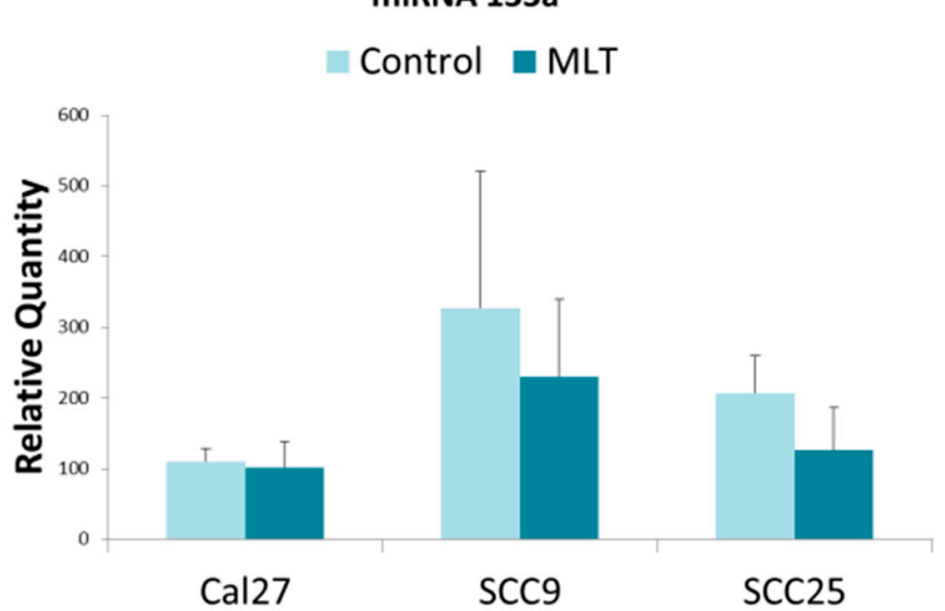

Figure 2. Relative miR-133a expression in oral cancers under melatonin (MLT) administration. Histogram of quantitative PCR from cDNAs derived from extracellular vesicles demonstrated differential baseline expression of miR-133a including standard deviation (SD), which was not significantly altered in any cell line under melatonin administration (CAL27, $p=0.11$; SCC9, $p=0.634$; SCC25, $p=0.411)$.

Finally, the results for miR-155 confirmed each of the oral cancer cell lines contained miR-155 in the extracellular vesicles, revealing that each cell line also exhibited differential expression (Figure 3). The lowest level of baseline miR-155 expression was observed in CAL27, with relatively higher levels observed in SCC9 and even greater expression among SCC25 cells. Interestingly, the addition of melatonin significantly decreased miR-155 expression in all three cell lines, $p<0.05$ (CAL27, $p<0.001$; SCC9, $p=0.003 ;$ SCC25, $p=0.039$ ). 
MiRNA 155

Control $\square \mathrm{MLT}$

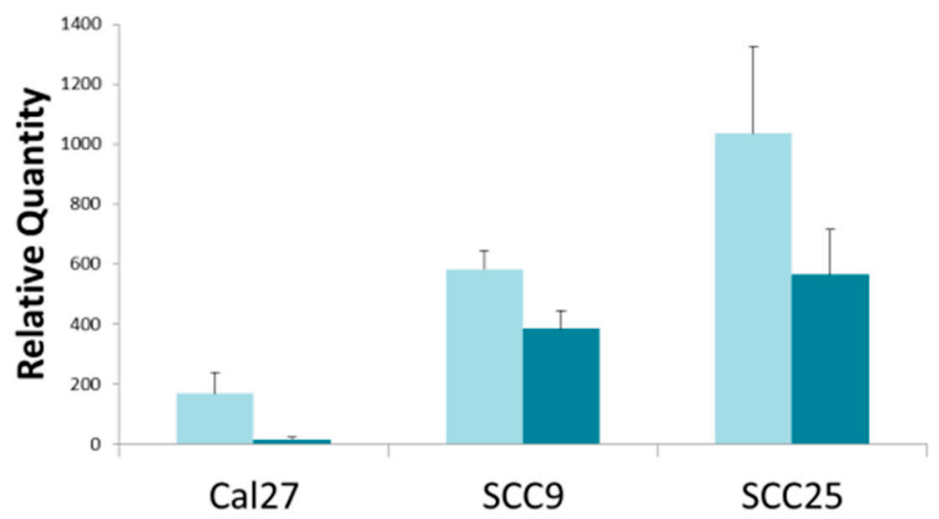

Figure 3. Relative miR-155 expression in oral cancers under melatonin (MLT) administration. Histogram of quantitative PCR from cDNAs derived from extracellular vesicles demonstrated differential baseline expression of miR-155 including standard deviation (SD). Administration of melatonin significantly reduced expression of miR-155 in all three cell lines, $p<0.05$ (CAL27, $p<0.001$; SCC9, $p=0.003$; SCC25, $p=0.039$ ).

To provide a comparison of the effects of melatonin on these microRNAs, the relative fold change in microRNA expression was plotted for each microRNA and oral cancer cell line (Figure 4). These data clearly reveal the inhibitory effect of melatonin on miR-155 in all three oral cancer cell lines. In addition, the significant increase in miR-21 expression following melatonin administration is demonstrated—with the greatest effects observed among the SCC9 and CAL27 cell lines.

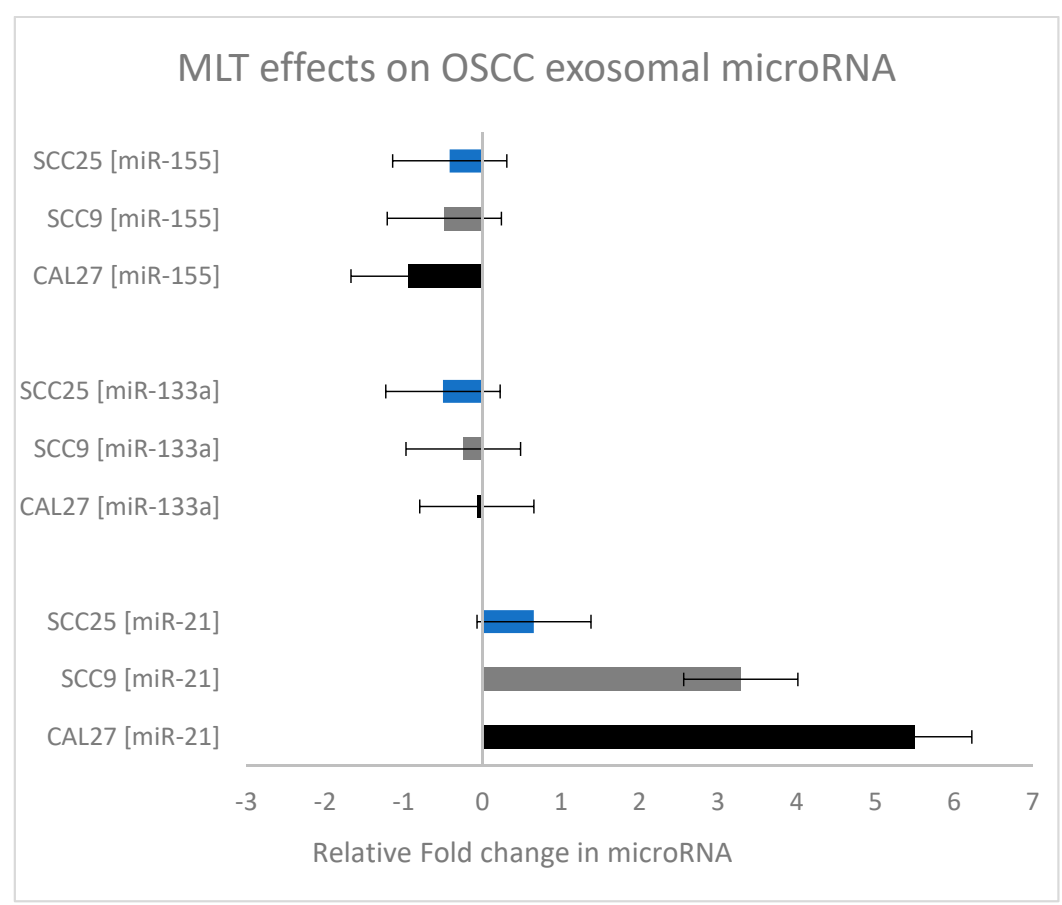

Figure 4. Relative fold change in microRNA expression in oral cancers under melatonin (MLT) administration. Calculation of the relative fold change in miRNA expression (experimental/baseline control) revealed significant increases in miR-21, with relatively little change to miR-133a and some inhibition of miR-155 (particularly in the CAL27 cells). 
Finally, to evaluate any effects of melatonin administration on the endogenous control, levels miR-16 were also evaluated (Table 1 ). These data suggest no significant differences in miR-16 expression between treated and untreated cells from this experiment.

Table 1. Analysis of miR-16 expression.

\begin{tabular}{ccc}
\hline Cell Type & Control miR-16 $\mathbf{C}_{\mathbf{T}}$ & Melatonin miR-16 $\mathbf{C}_{\mathbf{T}}$ \\
\hline SCC9 & $29.3 \pm 0.23$ & $29.5 \pm 0.27$ \\
SCC25 & $30.3 \pm 0.11$ & $29.9 \pm 0.32$ \\
Cal27 & $35.6 \pm 0.31$ & $35.7 \pm 0.24$ \\
\hline
\end{tabular}

\section{Discussion}

Although previous studies from this group have evaluated changes to oral cancer gene expression under melatonin administration (as well as differential expression of oral cancer extracellular vesicles, exosomes, and microRNAs) no studies to date have analyzed the effects of melatonin on microRNA expression in oral cancers $[27,28]$. This study was able to successfully evaluate the effects of melatonin administration on the expression of specific microRNAs, such as miR-21, miR-133a and miR-155 among specific oral cancer cell lines, including CAL27, SCC9 and SCC25. These data clearly demonstrated differential responses between each cell line, as well as between each specific microRNA.

For example, the expression of miR-21 has been demonstrated to be a useful biomarker and prognostic tool, which is strongly correlated with decreased survival [31,32]. This specific microRNA has been proposed in several independent studies as one of the critical factors that might be involved with oral squamous cell carcinoma progression [33-35]. Although melatonin has been associated with tumor inhibition in other studies [8-10], this study is the first to assess the effect of melatonin on miR-21 in exosome and extracellular vesicle RNA from oral cancers. One potential explanation for the surprising observations in this study that demonstrated increased miR-21 expression following melatonin administration relates to the variety of transcription factor binding sites in the miR-21 promoter regions, including AP1, STAT3 and many others [36,37]. It is possible that many other transcriptional mediators, such as melatonin, may also facilitate miR-21 transcription-although no temporal (or longer-term) information was gathered from this study to determine if miR-21 expression remains stable under melatonin supplementation.

The inhibition of miR-155 under melatonin administration was significant, as miR-155 is known to modulate additional pathways of cellular proliferation and apoptosis in oral cancers through p27Kip1 and BCL6/cyclin D2 [38,39]. That melatonin administration may be associated with down-regulation of miR-155 expression may appear to support previous observations that miR-155 is an important regulator of oral squamous cell carcinoma metastasis and is associated with poor prognosis [40,41]. In fact, recent evidence has suggested that miR-155 may be a critical transcriptional activator and prognostic biomarker that may be sufficient to induce changes to oral cancer proliferation [42]. One previous study did report that melatonin administration inhibited proliferation and invasion of glioma cells through transcriptional repression of miR-155, although no other study to date has evaluated these effects among oral cancers [24].

It important to note that these may be the first published evidence of these effects among oral cancers and will need to be further strengthened by other studies that include additional oral cancer cell lines, as well as primary tumor isolates. It would also be important to note that the study limitations did not allow for longer term, temporal analysis of melatonin-induced changes to these cellular phenotypes-which will be an important component of future studies from this group. However, previous studies from this group have identified reductions in cellular viability in response to melatonin, which may be important for contextualizing these results [43,44]. Finally, there are many additional microRNAs that may be important mediators of clinical outcomes and cellular phenotypes-therefore, future studies should also evaluate any potential effects of melatonin on these microRNAs [45,46]. 


\section{Conclusions}

Although many studies have documented changes in gene expression among various cancers under melatonin administration, few studies have evaluated these effects on microRNAs. These results may be among the first to evaluate the effects of melatonin on microRNA expression in oral cancers, which suggests the differential modulation of specific microRNAs, such as miR-21, and miR-155, may be of significant importance when evaluating the mechanisms and pathways involved in melatonin-associated anti-tumor effects.

Author Contributions: K.M.H. and K.K. were responsible for the overall project design. M.H. and G.B. were responsible for all experimental protocols and procedures. All authors contributed to the writing of this manuscript.

Acknowledgments: The authors would like to acknowledge the University of Nevada, Las Vegas-Graduate and Professional Student Association (GPSA) and the School of Dental Medicine (UNLV-SDM) Office of Research for initial funding for this project.

Conflicts of Interest: The authors declare no conflict of interest.

\section{References}

1. Beresford, B.; McDaid, C.; Parker, A.; Scantlebury, A.; Spiers, G.; Fairhurst, C.; Hewitt, C.; Wright, K.; Dawson, V.; Elphick, H.; et al. Pharmacological and non-pharmacological interventions for non-respiratory sleep disturbance in children with neurodisabilities: A systematic review. Health Technol. Assess. 2018, 22, 1-296. [CrossRef]

2. Fernandez, R.C.; Moore, V.M.; Van Ryswyk, E.M.; Varcoe, T.J.; Rodgers, R.J.; March, W.A.; Moran, L.J.; Avery, J.C.; McEvoy, R.D.; Davies, M.J. Sleep disturbances in women with polycystic ovary syndrome: Prevalence, pathophysiology, impact and management strategies. Nat. Sci. Sleep 2018, 10, 45-64. [CrossRef]

3. Blackmer, A.B.; Feinstein, J.A. Management of Sleep Disorders in Children with Neurodevelopmental Disorders: A Review. Pharmacotherapy 2016, 36, 84-98. [CrossRef]

4. Simko, F.; Baka, T.; Paulis, L.; Reiter, R.J. Elevated heart rate and nondipping heart rate as potential targets for melatonin: A review. J. Pineal Res. 2016, 61, 127-137. [CrossRef]

5. Lima, W.R.; Holder, A.A.; Garcia, C.R. Melatonin signaling and its modulation of PfNF-YB transcription factor expression in Plasmodium falciparum. Int. J. Mol. Sci. 2013, 14, 13704-13718. [CrossRef] [PubMed]

6. Bruni, O.; Alonso-Alconada, D.; Besag, F.; Biran, V.; Braam, W.; Cortese, S.; Moavero, R.; Parisi, P.; Smits, M.; Van der Heijden, K.; et al. Current role of melatonin in pediatric neurology: Clinical recommendations. Eur. J. Paediatr. Neurol. 2015, 19, 122-133. [CrossRef]

7. Chen, S.; Shi, L.; Liang, F.; Xu, L.; Desislava, D.; Wu, Q.; Zhang, J. Exogenous Melatonin for Delirium Prevention: A Meta-analysis of Randomized Controlled Trials. Mol. Neurobiol. 2016, 53, 4046-4053. [CrossRef] [PubMed]

8. Frenkel, M.; Abrams, D.I.; Ladas, E.J.; Deng, G.; Hardy, M.; Capodice, J.L.; Winegardner, M.F.; Gubili, J.K.; Yeung, K.S.; Kussmann, H.; et al. Integrating dietary supplements into cancer care. Integr. Cancer Ther. 2013, 12, 369-384. [CrossRef] [PubMed]

9. Najafi, M.; Salehi, E.; Farhood, B.; Nashtaei, M.S.; Hashemi Goradel, N.; Khanlarkhani, N.; Namjoo, Z.; Mortezaee, K. Adjuvant chemotherapy with melatonin for targeting human cancers: A review. J. Cell. Physiol. 2019, 234, 2356-2372. [CrossRef]

10. Menéndez-Menéndez, J.; Martínez-Campa, C. Melatonin: An Anti-Tumor Agent in Hormone-Dependent Cancers. Int. J. Endocrinol. 2018, 2018, 3271948. [CrossRef]

11. Lemanne, D.; Maizes, V. Advising Women Undergoing Treatment for Breast Cancer: A Narrative Review. J. Altern. Complement. Med. 2018, 24, 902-909. [CrossRef]

12. Tamtaji, O.R.; Mirhosseini, N.; Reiter, R.J.; Behnamfar, M.; Asemi, Z. Melatonin and pancreatic cancer: Current knowledge and future perspectives. J. Cell. Physiol. 2018, 234, 5372-5378. [CrossRef]

13. Favero, G.; Moretti, E.; Bonomini, F.; Reiter, R.J.; Rodella, L.F.; Rezzani, R. Promising Antineoplastic Actions of Melatonin. Front. Pharmacol. 2018, 9, 1086. [CrossRef]

14. Farhood, B.; Goradel, N.H.; Mortezaee, K.; Khanlarkhani, N.; Najafi, M.; Sahebkar, A. Melatonin and cancer: From the promotion of genomic stability to use in cancer treatment. J. Cell. Physiol. 2019, 234, 5613-5627. [CrossRef] 
15. Bondy, S.C.; Campbell, A. Mechanisms Underlying Tumor Suppressive Properties of Melatonin. Int. J. Mol. Sci. 2018, 19, 2205. [CrossRef]

16. D'souza, S.; Addepalli, V. Preventive measures in oral cancer: An overview. Biomed. Pharmacother. 2018, 107, 72-80. [CrossRef]

17. Majka, J.; Wierdak, M.; Brzozowska, I.; Magierowski, M.; Szlachcic, A.; Wojcik, D.; Kwiecien, S.; Magierowska, K.; Zagajewski, J.; Brzozowski, T. Melatonin in Prevention of the Sequence from Reflux Esophagitis to Barrett's Esophagus and Esophageal Adenocarcinoma: Experimental and Clinical Perspectives. Int. J. Mol. Sci. 2018, 19, 2033. [CrossRef]

18. Yeh, C.M.; Su, S.C.; Lin, C.W.; Yang, W.E.; Chien, M.H.; Reiter, R.J.; Yang, S.F. Melatonin as a potential inhibitory agent in head and neck cancer. Oncotarget 2017, 8, 90545-90556. [CrossRef]

19. Mehta, A.; Kaur, G. Potential role of melatonin in prevention and treatment of oral carcinoma. Indian J. Dent. 2014, 5, 86-91. [CrossRef]

20. Cutando, A.; López-Valverde, A.; DEVicente, J.; Gimenez, J.L.; Carcía, I.A.; de Diego, R.G. Action of melatonin on squamous cell carcinoma and other tumors of the oral cavity (Review). Oncol. Lett. 2014, 7, 923-926. [CrossRef]

21. Wang, T.H.; Hsueh, C.; Chen, C.C.; Li, W.S.; Yeh, C.T.; Lian, J.H.; Chang, J.L.; Chen, C.Y. Melatonin Inhibits the Progression of Hepatocellular Carcinoma through MicroRNA Let7i-3p Mediated RAF1 Reduction. Int. J. Mol. Sci. 2018, 19, 2687. [CrossRef]

22. Marques, J.H.M.; Mota, A.L.; Oliveira, J.G.; Lacerda, J.Z.; Stefani, J.P.; Ferreira, L.C.; Castro, T.B.; Aristizábal-Pachón, A.F.; Zuccari, D.A.P.C. Melatonin restrains angiogenic factors in triple-negative breast cancer by targeting miR-152-3p: In vivo and in vitro studies. Life Sci. 2018, 208, 131-138. [CrossRef]

23. Zhu, C.; Huang, Q.; Zhu, H. Melatonin Inhibits the Proliferation of Gastric Cancer Cells through Regulating the miR-16-5p-Smad3 Pathway. DNA Cell Biol. 2018, 37, 244-252. [CrossRef]

24. Gu, J.; Lu, Z.; Ji, C.; Chen, Y.; Liu, Y.; Lei, Z.; Wang, L.; Zhang, H.T.; Li, X. Melatonin inhibits proliferation and invasion via repression of miRNA-155 in glioma cells. Biomed. Pharmacother. 2017, 93, 969-975. [CrossRef]

25. Guo, N.; Zhao, Y.; Zhang, W.; Li, S.; Li, S.; Yu, J. MicroRNA-133a downregulated EGFR expression in human non-small cell lung cancer cells via AKT/ERK signaling. Oncol. Lett. 2018, 16, 6045-6050. [CrossRef]

26. Rusanova, I.; Diaz-Casado, M.E.; Fernández-Ortiz, M.; Aranda-Martínez, P.; Guerra-Librero, A.; García-García, F.J.; Escames, G.; Mañas, L.; Acuña-Castroviejo, D. Analysis of Plasma MicroRNAs as Predictors and Biomarkers of Aging and Frailty in Humans. Oxid. Med. Cell. Longev. 2018, 2018, 7671850. [CrossRef]

27. Brennan, D.; Patel, K.; Howard, N.; Kingsley, K.; Howard, K. Differential miRNA Expression in Oral Cancer Oncosomes: A Pilot In Vitro Study. Int. Res. J. Oncol. 2018, 1, 1-9. [CrossRef]

28. Hartounian, A.; Retis, G.A.; Kingsley, K.; Howard, K.M. Alterations in Oral Cancer Gene Expression in Response to Melatonin. J. Complement. Altern. Med. Res. 2018, 6, 1-8. [CrossRef]

29. Chojnacki, C.; Wachowska-Kelly, P.; Błasiak, J.; Reiter, R.J.; Chojnacki, J. Melatonin secretion and metabolism in patients with hepatic encephalopathy. J. Gastroenterol. Hepatol. 2013, 28, 342-347. [CrossRef]

30. Chojnacki, C.; Walecka-Kapica, E.; Klupińska, G.; Wachowska-Kelly, P.; Żylińska, K.; Winczyk, K.; Chojnacki, J. Serotonin and melatonin secretion and metabolism in patients with liver cirrhosis. Pol. Arch. Med. Wewn. 2012, 122, 392-397. [CrossRef]

31. Guraya, S. Prognostic significance of circulating microRNA-21 expression in esophageal, pancreatic and colorectal cancers; a systematic review and meta-analysis. Int. J. Surg. 2018, 60, 41-47. [CrossRef]

32. Harrandah, A.M.; Mora, R.A.; Chan, E.K.L. Emerging microRNAs in cancer diagnosis, progression, and immune surveillance. Cancer Lett. 2018, 438, 126-132. [CrossRef]

33. Gissi, D.B.; Morandi, L.; Gabusi, A.; Tarsitano, A.; Marchetti, C.; Cura, F.; Palmieri, A.; Montebugnoli, L.; Asioli, S.; Foschini, M.P.; et al. A Noninvasive Test for MicroRNA Expression in Oral Squamous Cell Carcinoma. Int. J. Mol. Sci. 2018, 19, 1789. [CrossRef]

34. Yap, T.; Koo, K.; Cheng, L.; Vella, L.J.; Hill, A.F.; Reynolds, E.; Nastri, A.; Cirillo, N.; Seers, C.; McCullough, M. Predicting the Presence of Oral Squamous Cell Carcinoma Using Commonly Dysregulated MicroRNA in Oral Swirls. Cancer Prev. Res. 2018, 11, 491-502. [CrossRef]

35. Zeljic, K.; Jovanovic, I.; Jovanovic, J.; Magic, Z.; Stankovic, A.; Supic, G. MicroRNA meta-signature of oral cancer: Evidence from a meta-analysis. Ups. J. Med. Sci. 2018, 123, 43-49. [CrossRef] 
36. Diederichs, S.; Bartsch, L.; Berkmann, J.C.; Fröse, K.; Heitmann, J.; Hoppe, C.; Iggena, D.; Jazmati, D.; Karschnia, P.; Linsenmeier, M.; et al. The dark matter of the cancer genome: Aberrations in regulatory elements, untranslated regions, splice sites, non-coding RNA and synonymous mutations. EMBO Mol. Med. 2016, 8, 442-457. [CrossRef]

37. Baer, C.; Claus, R.; Plass, C. Genome-wide epigenetic regulation of miRNAs in cancer. Cancer Res. 2013, 73, 473-477. [CrossRef]

38. Fu, S.; Chen, H.H.; Cheng, P.; Zhang, C.B.; Wu, Y. MiR-155 regulates oral squamous cell carcinoma Tca8113 cell proliferation, cycle, and apoptosis via regulating p27Kip1. Eur. Rev. Med. Pharmacol. Sci. 2017, 21, 937-944.

39. Zeng, Q.; Tao, X.; Huang, F.; Wu, T.; Wang, J.; Jiang, X.; Kuang, Z.; Cheng, B. Overexpression of miR-155 promotes the proliferation and invasion of oral squamous carcinoma cells by regulating BCL6/cyclin D2. Int. J. Mol. Med. 2016, 37, 1274-1280. [CrossRef]

40. Baba, O.; Hasegawa, S.; Nagai, H.; Uchida, F.; Yamatoji, M.; Kanno, N.I.; Yamagata, K.; Sakai, S.; Yanagawa, T.; Bukawa, H. MicroRNA-155-5p is associated with oral squamous cell carcinoma metastasis and poor prognosis. J. Oral Pathol. Med. 2016, 45, 248-255. [CrossRef]

41. Manikandan, M.; Deva Magendhra Rao, A.K.; Rajkumar, K.S.; Rajaraman, R.; Munirajan, A.K. Altered levels of miR-21, miR-125b-2*, miR-138, miR-155, miR-184, and miR-205 in oral squamous cell carcinoma and association with clinicopathological characteristics. J. Oral Pathol. Med. 2015, 44, 792-800. [CrossRef]

42. Ni, Y.H.; Huang, X.F.; Wang, Z.Y.; Han, W.; Deng, R.Z.; Mou, Y.B.; Ding, L.; Hou, Y.Y.; Hu, Q.G. Upregulation of a potential prognostic biomarker, miR-155, enhances cell proliferation in patients with oral squamous cell carcinoma. Oral Surg. Oral Med. Oral Pathol. Oral Radiol. 2014, 117, 227-233. [CrossRef]

43. Farnoush, M.; Swint, D.; Kingsley, K. Evidence for Biphasic Effects and Differential Expression of Melatonin (MLT) Receptors in Oral Squamous Cell Carcinomas. BOAJ Cancer Sci. 2015, 1, 1-5.

44. Fabrega, J.; Robison, J.; Farnoush, M.; Kingsley, K. Melatonin (MLT) affects the proliferation and viability of oral squamous cell carcinoma lines. Forum Dent. Stud. Res. Innov. (FDSRI) Fall 2013, 1, 12-19.

45. Domingues, C.S.D.C.; Serambeque, B.P.; Laranjo Cândido, M.S.; Marto, C.M.M.; Veiga, F.J.B.; Sarmento Antunes Cruz Ribeiro, A.B.; Figueiras, A.R.R.; Botelho, M.F.R.; Dourado, M.A.R.F. Epithelial-mesenchymal transition and microRNAs: Challenges and future perspectives in oral cancer. Head Neck. 2018, 40, 2304-2313. [CrossRef]

46. Siriwardena, S.B.S.M.; Tsunematsu, T.; Qi, G.; Ishimaru, N.; Kudo, Y. Invasion-Related Factors as Potential Diagnostic and Therapeutic Targets in Oral Squamous Cell Carcinoma-A Review. Int. J. Mol. Sci. 2018, 19, 1462. [CrossRef]

(C) 2019 by the authors. Licensee MDPI, Basel, Switzerland. This article is an open access article distributed under the terms and conditions of the Creative Commons Attribution (CC BY) license (http://creativecommons.org/licenses/by/4.0/). 